\title{
Streeteiros e a cidade: Sociabilidades, itinerários e institucionalização do skate em Imperatriz-MA
}

Jesus Marmanillo Pereira'

Resumo: O presente artigo tem como objetivo demonstrar aspectos da sociabilidade e da história pelo viés do skate street, na cidade de Imperatriz, no Maranhão. Com isso, buscamos compreender as tensões e coesões que propiciaram o processo de "institucionalização" da prática do skate local. Com base em uma perspectiva de sociologia urbana que transfere o foco analítico da cidade para os atores sociais, focamos nosso campo de estudo sobre as relações entre sete membros das duas principais marcas locais de peças de skate e as interações desenvolvidas por eles.

Palavras-chave: Skate, Imperatriz, sociabilidades.

Streeteiros and the city: Sociabilities, itineraries and institutionalization of skateboarding in Imperatriz-MA

Abstract: This paper aims to demonstrate aspects of sociability and history from skate street in the city of Imperatriz, Maranhão. With this, we seek to understand the tensions and cohesions that led to the process of "institutionalization" of the practice of local skateboarding. Starting from an urban sociology perspective that shifts the analytical focus of the city to the social actors, we had our field on

1 Programa de Pós-Graduação em Sociologia da Universidade Federal do Maranhão (PPGS-UFMA) Imperatriz - Brasil - laepciufma@gmail.com 
the relations between seven members of the two main local brands of skateboard parts and the interactions developed by them.

\section{Keywords: Skateboard, Imperatriz, sociabilities.}

\section{INTRODUC, ÃO}

Segundo a Confederação Brasileira de Skate $(\mathrm{CBS})^{2}$, entre 2009 e 2015, ocorreu um aumento de quase $100 \%$ no número de skatistas no Brasil, que passaram de 3,9 milhões para 8,5 milhões em todo o território nacional. Trata-se de uma verdadeira população de jovens espalhada por diversos centros urbanos do país ou, nas palavras de Brandão (2011), de flaneurs da contemporaneidade que tomaram as ruas, as praças e as avenidas das cidades como um grande parque de diversões constituído na aspereza do cimento.

No centro de Imperatriz-MA3 ${ }^{3}$, é possível observar parte dessa realidade na pista de skate (skatepark) da Praça Mané Garrincha, e em relatos que apontam a existência da prática do skate street (skate de rua) em períodos que remontam a um intervalo entre o fim da década de 1980 e o início dos anos 1990. Enfim, a dinâmica social do skate nesse lugar pode ser caracterizada na existência de duas fábricas de shape, de lojas especializadas em material esportivo e em um trabalho social de vários atores que resultou na produção de eventos regionais e na promoção da prática de skate, como foram os casos dos circuitos nordestinos Qix 2007 e 2008.

Os primeiros contatos com os jovens skatistas foram estabelecidos pela internet e depois no skatepark da Praça Mané Garrincha - local que representa uma "conquista" por ser o marco na história social do skate em Imperatriz, e traduzir um conjunto de ações, eventos e sociabilidades desenvolvidas em torno dessa prática ao longo das três últimas décadas. Nessa perspectiva da compreensão da consolidação desse hábito urbano e jovem, o presente artigo analisará um conjunto de interações de um universo composto por sete jovens que são representativos de três gerações de skatistas e que integram duas equipes concorrentes de marcas de produtos de skate. Buscou-se, com isso, compreender as

2 Disponível em: <http://triboskate.ativo.com/datafolha-atualiza-para-85-milhoes-o-numero-de-skatistas-no-brasil/>. Acesso em: 11 set. 2019.

3 É importante contextualizar que não estamos tratando de uma metrópole ou cidade grande, mas de uma cidade maranhense que possui 247.505 habitantes (IBGE), que está localizada no sudoeste do estado na margem direita do rio Tocantins e é considerada a segunda maior do estado. Nesse sentido, a própria prática do skate, assim como outros hábitos dos jovens imperatrizenses também sinaliza a expansão e difusão de uma estética global, norte americana, que se manifestou no Brasil, durante a década de 1970, nas cidades do Rio de Janeiro e São Paulo. 
tensões e ações que propiciaram o processo de "institucionalização" ou aceitação maior do skate na cidade de Imperatriz-MA.

Para entender esse universo, uma contribuição importante é a de Telles (2010, p. 86), pois compreende a relação entre espaço e tempo, considerando que "as práticas urbanas deixam suas marcas no espaço e estas se objetivam, ganham forças e constroem referências que permitem entrecruzamentos com outras histórias, outros percursos, outros eventos que pontilham a história urbana”. Nesse sentido, buscou-se descrever um movimento que ocupou espaços, tempos e que ganhou forma graças aos percursos de determinados atores sociais.

Tentou-se seguir uma orientação teórico-metodológica próxima do interacionismo e ancorada nas etnografias de Whyte (2005), Aderaldo (2017), Pereira (2017), entre outros que, grosso modo, ao analisarem grupos jovens e coletivos, demonstram uma rica operacionalização de campo fundamentada no mapeamento de redes de relações interpessoais e nas descrições de processos de sociabilidade urbana. Outra influência importante foi Agier (2011), quando propõe, nos estudos de sociologia e antropologia, um deslocamento das cidades para os atores, a fim de buscar o "Fazer a cidade". Já autores como Frúgoli (2007), Magnani (2010), Bourdieu (1983), Pais (1990), Dayrell (2003), Machado (2012) e Diógenes (1998) foram fundamentais na problematização da questão da juventude, sinalizando que um caminho importante para a compreensão do grupo passa pela desnaturalização do termo, da forma como é difundido nas representações sociais e na mídia. Com base nesse referencial e em um conjunto de sete entrevistas, fotografias dos acervos pessoais dos entrevistados, fotografias produzidas em campo, pesquisa em jornais da época e observações diretas realizadas ao longo do primeiro semestre de $2017^{4}$,

4 Sobre o processo de pesquisa, é importante ressaltar que se trata de um primeiro esforço do recém-criado (2016) Laboratório de Estudos e Pesquisas sobre Cidades e Imagens (LAEPCI-UFMA). Na ocasião, tentou-se executar uma iniciação científica com o plano de trabalho "Sociedade da Praça: a organização e as interações nas pistas de skate na Praça Mané Garrincha em Imperatriz-MA”, no entanto, não logramos êxito, já que o discente alegava dificuldades de realizar o encontro com um informante. Ele nos informou, também, que o lugar era perigoso e que existia um tráfico, tendo sido assaltado no lugar. Entre essas tentativas frustradas, foram-se seis meses. Com esse contexto de inviabilidade de realização e com os prazos andando, decidi fazer os contatos e buscar uma aproximação com os jovens skatistas que frequentavam aquele local. As redes sociais da internet foram o primeiro local de observação e por meio desse ambiente tive contato com um jovem skatista que me possibilitou transitar com mais conforto por aquele meio. No âmbito do controle de impressões, creio que o meu estilo cabeludo, com camisa de banda, brincos e pulseiras favoreceu a aproximação, a idade de 38 anos e todo o contato com a cultura de massa das décadas de 80 e 90 foram um ponto que geraram certo conforto nos diálogos das primeiras gerações de skatistas locais. $\mathrm{O}$ fato de andar de bike foi outra característica que gerou certa atração, chegando ao ponto de receber convites para participar de trilhas. No geral, foi possível obter 15 entrevistas, fotografias antigas dos acervos de alguns skatistas e registros feitos, com o próprio auxílio deles, já que dominam um olhar fotográfico especializado na observação das manobras. 
o texto foi organizado em duas partes nas quais serão expostos aspectos da história social ancorada nas marcas de shape em Imperatriz.

\section{A equipe da Go Skateboard}

Tendo como principal operacionalização a transposição do foco da cidade para os citadinos, e o deslocamento da problemática do objeto para o sujeito, ou seja, da questão "sobre o que é cidade?" para a pergunta "sobre o que faz a cidade?", Agier (2011) encontrou apoio em estudos como os de Aderaldo (2017), que analisou os processos de sociabilidade, mais alargada e heterogênea, por meio da observação das mobilidades exercidas por jovens de coletivos ligados à produção de vídeos populares. Já os estudos de Eckert e Rocha $(2013,2013 a)$ enfatizam os itinerários e experiências dos atores sociais na cidade, oferecendo especial atenção aos deslocamentos espaços-temporais vividos e lembrados.

Seguindo esse viés, obteve-se um primeiro contato, por uma rede social na internet, com o um jovem chamado Leonardo Clemente Alves de Castro (Conhecido como Leonardo Clemente), no dia 18 de fevereiro de 2017. Pode-se dizer que ele foi uma espécie de doc inicial5 (Whyte, 2005), um importante informante por meio do qual foi possível adentrar no cotidiano dos praticantes de skate street e fugir das versões extraordinárias que narravam a Praça Mané Garrincha como, apenas, local de violência, drogas e vagabundagem. Tais versões podem ser verificadas na imprensa local ${ }^{6}$, e segundo os entrevistados, as próprias mães deles também possuíam uma visão estigmatizante a respeito da praça.

Além dessa representação do lugar, diretamente associada aos seus frequentadores, foi importante considerar também a crítica de Pais (1990) quando observa que muitos trabalhos sociológicos têm funcionado como verdadeiras "caixas de ressonância" dos meios de comunicação de massa, tomando os estilos de vida como dados sem uma problematização mais séria. Além disso, esse autor ressalta que, mais que analisar a juventude com base em uma cultura dominante (geracional ou de classe), é importante analisar os processos de socialização nos níveis micro e macrossociológico, buscando compreender os modos

5 Sobre isso, vale dizer que, por meio dos primeiros contatos com Leonardo Clemente, obtivemos a indicação de Claudio Secco e de Japa, respectivos proprietários das marcas Hard Flip e Go Skateboard, como importantes nomes na cena do skate local. Esses dois, por sua vez, possibilitaram-nos a comunicação, respectivamente, com Junior e Faraó. O contato com Tico aconteceu com o apoio de Cleiton Viana, que é artista de rua e conhece Tico por conta da participação deles na Trupe de Habilidades Circenses.

6 Disponível em: <http://www.jhivagosales.com.br/2016/o7/policia-apreende-11-jovens-na-praca.html>. Acesso em: 11 set. 2019.

Disponível em: <https://imirante.com/imperatriz/noticias/2014/08/28/preso-suspeito-de-trafico-de-drogasem-imperatriz.shtml>. Acesso em: 11 set. 2019. 
de vida. Em linha similar, compreende-se que devem ser tomados não apenas pelo que possuem de costumes em comum, mas também considerando as diferenças existentes entre eles, compreendendo-os como uma microsociedade marcada por processos de consenso e conflito inerentes ao desenvolvimento de uma construção identitária.

No contato realizado na Praça Mané Garrincha, o primeiro sinal da presença de Leonardo Clemente foi com o barulho do rolamento do skate sobre a calçada do Estádio Frei Epitáfio, localizado ao lado da Praça. À primeira vista, apenas um jovem segmentário da estética global, com tênis, calça jeans e um estilo que se repete nas mais variadas cidades do Brasil e do mundo. Contudo, com um pouco mais de diálogo e convívio, foi possível observá-lo dentro de um processo de socialização contínua (PAIS, 1990)7 por meio da qual constrói o próprio papel social dentro do cenário do skate local. Ou seja, o ator social ia se construindo como atleta de acordo com o desenvolvimento de seus processos de sociabilidades (Frúgoli, 2007) que os ligam a uma rede mais ampla e marcada por outras gerações de skatistas daquele lugar.

Primeiramente, o jovem de 18 anos - anda de skate desde 2012 e mora no bairro periférico chamado Santa Rita - é financiado e orientado pela Go Skeatboard que, atualmente, é de propriedade de outro skatista chamado Wanderson Ferreira (também conhecido como Japa). O contato entre eles ocorreu na Praça Mané Garrincha, lugar cujo ambiente recreativo é apropriado para o skate: munido de rampas e equipamentos urbanos específicos para essa prática. Nesse lugar, classificado pelos skatistas como skate park, desenvolveram-se as relações de amizade e troca de experiências entre os dois.

Para o jovem Leonardo Clemente, a experiência do patrocinador é importante por se tratar de uma pessoa com, aproximadamente, 16 anos de experiência na prática do esporte. 0 "Japa" possui 29 anos e iniciou-se na prática do skate, em 2002, nas ruas de Davinópolis, sua antiga cidade, localizada a $27,8 \mathrm{~km}$ do centro de Imperatriz. Nessa prática de skate de rua, também conhecida como Skate Street, ele teve contato com Divino Noleto Freitas (também conhecido como Junior), naquele mesmo ano. Então, passou a desenvolver o Skate street também em Imperatriz, e explica: "eu vinha de Davinópolis para andar aqui. $\mathrm{Na}$

7 Isso não significa que não ocorressem tensões geracionais, os conflitos e tensões ocorriam geralmente nos processos de integração de gerações, quando os jovens atletas adotavam posturas que iam contra as concepções de conduta da vida, adotadas pelos patrocinadores e skatistas veteranos. Durante o trabalho de campo, observei que quando um jovem skatista tinha um comportamento voltado para as bebidas, festas e excessos, os patrocinadores e skatistas veteranos mais empenhados na construção de uma boa imagem pública manifestavam-se de forma similar a uma consciência coletiva contra uma atitude criminosa. 
época, os amigos iam lá pedir para mamãe para me liberar" (Ferreira, Wanderson Silva, entrevista realizada em 01/03/2017).

Após 2007 , ele passou a ser patrocinado pela Go Skeatboard, que na época era de propriedade de seu amigo Junior. Das relações de amizade construídas no lazer promovido pelo skate street, esses dois buscaram profissionalizar aquela prática em torno da marca, que foi comprada por "Japa" em 2013. Provavelmente por conta disso, o próprio entrevistado relata que, a partir de 2007, as relações se estreitaram. Sobre isso, observou que a aproximação maior era em decorrência de não se tratar apenas de uma relação de amizade e lazer nas ruas, mas também de relações estabelecidas nos campeonatos em Imperatriz e em outras cidades, nas atividades da pista de skate da marca e na fabricação de shapes.

Já o fundador da Go Skeatboard, de 38 anos, obteve o primeiro contato com o skate em 1991, aos doze anos de idade (2 anos mais novo que os dois anteriores), na área do edifício Meridien, um dos primeiros prédios verticais de alto padrão construído no bairro Nova Imperatriz, em 1990. Segundo ele, o contato decisivo com o skate ocorreu na área de seu próprio prédio, quando observou um jovem fazendo manobras Free Style, o que lhe chamou muito atenção. Sobre isso, ele explica:

Aí eu comecei a pegar amizade com ele, Ele era novo no prédio, ele veio de São Paulo. Ele já tava andando com a galera daqui, daí ele disse que tinha uma loja aqui (...). Ele me trouxe pra loja, daí eu vi só peça massa lá. A galera andando, me chamaram pra andar no sábado. Daí eu vim e os caras andavam pra Caral...! Comecei a fazer amizade com os caras e a gente andava na rua. (Freitas, Divino Junior, entrevista realizada em 04/03/2017, grifos nossos).

Se os contatos mais atuais entre Leonardo Clemente e "Japa" ocorreram no skatepark da Praça Mané Garrincha, os contatos entre Japa e Junior foram fruto da prática do skate de rua. Já a integração de Junior desenvolveu-se em dois aspectos, pois o amigo recém-chegado de São Paulo não só lhe apresentou a potencialidade daquele artefato, mas o colocou em contato com a Gringo Skate Wear, a primeira e única loja especializada, na época, em materiais de skate. Utilizando os termos de Magnani (2012), pode-se dizer que se trata do primeiro circuito de jovens skatistas de Imperatriz. Nesse viés, é possível descrever o espaço da loja como o ponto seminal para a primeira geração de skatistas da cidade.

Trata-se do primeiro lugar onde era possível concentrar os jovens que possuíam a expertise sobre o tema. Lugar onde era possível fazer contatos com outros jovens skatistas, como demonstrou Junior em seu relato, e lugar difusor 
de uma estética global (Diogenes, 1998) capaz de promover a inserção do jovem imperatrizense por meio da obtenção de determinadas formas de se vestir e de comportamentos que eram desenvolvidos naquele lugar. Para Diógenes (1998), tal estética seria responsável por produzir uma uniformidade entre os jovens de diferentes partes do mundo, por meio de determinados consumos comuns, que em outros termos significa que um skatista produzido na Gringo Skate Wear seria facilmente reconhecido como tal em qualquer cidade do mundo.

Embora os três casos apresentados fossem seguidores e compartilhadores de uma estética global (Diogenes, 1998) que os enquadra facilmente no rótulo de jovens skatistas, e enfatiza as ideias de liberdade, radicalidade e outras difundidas nos meios de comunicação de massa, em um olhar um pouco mais lento observa-se que, no âmbito da formação da Go Skeatboard, eles possuíam diferentes origens sociais e formas de inserção na prática do skate.

Os locais de moradia, a propriedade dos meios de produção dos shapes e as divisões do trabalho sinalizam uma diferenciação de classes, no sentido clássico marxista e weberiano. Seguindo o viés Bourdiano (1983), pode-se dizer que as diferenciações são objetivadas nas posições adotadas no âmbito da produção. Exemplo disso é quando se observa que o capital investido na criação da fábrica $^{8}$ da Go Skateboard, em 2003, foi proveniente da venda de um automóvel, pertencente a "Junior", e a um empréstimo feito pela própria mãe. Ainda nessa linha de conversão de patrimônio em capital é importante destacar que a empresa possuía uma pista de skate construída em 2007, na área do Freitas Park, que é de propriedade do próprio pai, o empresário Divino Freitas, que chegou na cidade no início da década de $1980^{9}$.

Para Weber (2004), isso seria uma situação de classe definida pela transferência do patrimônio para a esfera do emprego como capital. Assim, trata-se de uma situação de mercado que não está apartada da origem familiar. Diferentemente, o primeiro caso se manifestava como patrocinado, ou seja, recebe peças e manutenção do skate para divulgar a marca; já o segundo tem a inserção inicial como patrocinado, como instrutor e fabricador de shapes (oferecendo sua força de trabalho) e, posteriormente, tornou-se proprietário da fábrica, em 2013.

8 Como mito "fundador", Junior explica que comprava shapes na loja Hard Flip, de propriedade de Claudio Secco. Ele disse que pedia shapes de 6 lâminas, mais leves, porque se adequavam melhor ao seu próprio peso. Ele segue dizendo que o primeiro shape saiu bom, mas que o segundo saiu meio estranho, servindo de motivação para que ele pensasse shapes que fossem mais adaptáveis às características físicas das pessoas. Segundo a breve biografia presente no site do Freitas Park, o empresário foi um dos pioneiros no ramo fotográfico em Imperatriz. Ele abriu uma empresa fotográfica chamada Freitas Cine Fotos, em 1982, e liderou o mercado por um período de vinte anos. 
Imagem 1: Junior e Japa na fábrica de shapes da Go Skateboard

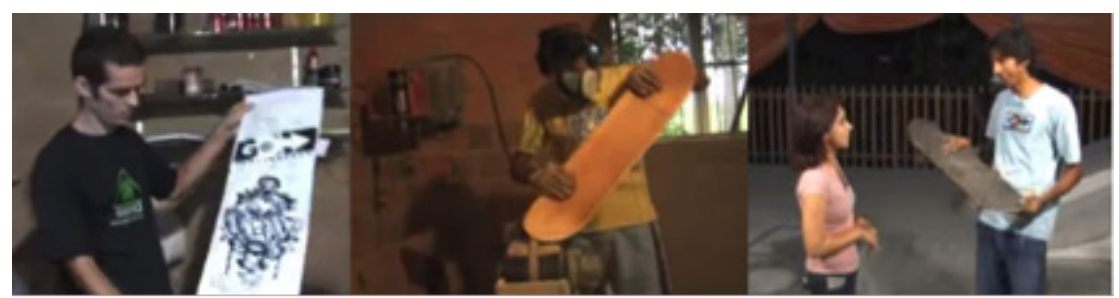

Fonte: Disponível em: <https://www.youtube.com/watch?v=P1Cbb9P4BEo $>$. Acesso em: 11 set. 2019.

Na imagem 1, composta de três frames extraídos de uma reportagem, exibida na TV Bandeirantes, em março de 2008, é possível visualizar “Japa”, de camisa azul clara, sendo instrutor na pista de skate da Go Skateboard, e também trabalhando, com camisa amarela, na fabricação de shapes na fábrica da empresa. Junior aparece exibindo uma serigrafia com a logomarca da empresa, explicando que está pronta para ser colocada no shape. É importante destacar que a reportagem foi produzida por Samuel Souza que, na época, tocava em uma banda de death metal com Junior.

Sobre isso, Boissevain (2010), em seu estudo sobre redes sociais e coalizões, observa que algumas pessoas conseguem exercer poder não pelo seu papel, mas pelo conjunto de contatos cultivados e estabelecidos. Para ele, as relações interpessoais são estruturadas e influenciadas, no modo como indivíduos - vistos como empreendedores sociais - buscam operacionalizá-las para atingir determinados fins.

A rede de relações interpessoais e o acúmulo de capitais econômicos, cultural e social (Bourdieu, 2001; Moore, 2018) são aspectos que podem ser alvo de reflexão neste estudo, já que, desde os primeiros contatos com o skate, Junior mobilizou uma série de recursos que foram desde o patrimônio familiar, o acesso às revistas especializadas, fitas de videocassete (recurso "caro" no início da década de 1990) e mobilização de um conjunto de agentes com características sociais similares que the propiciaram um habitus e um status dentro do campo.

Isso pode ser observado na própria construção da logomarca da empresa, quando o skatista-empresário contou com o auxílio de Daniel Tavares, de Fortaleza-CE, irmão mais novo do dono da empresa Pena Surf, no desenvolvimento do design da marca. Também foi auxiliado pelo skatista Marcelo Agra, um recifense pioneiro na fabricação de shapes que lhe possibilitou um curso de 15 dias em sua própria fábrica, em São Paulo. Ele explica que Daniel Tavares foi 
patrocinado pela Go Skateboard e que o primeiro shape dele tinha a assinatura da empresa. O skatista sergipano Julio Detefon também era patrocinado. Localmente, a equipe era composta por "Marquinhos" e "Japa", que eram da cidade vizinha de Davinópolis. Com a mobilização dessa rede, foi possível a realização dos campeonatos QIX Nordestinos de 2007 e 2008. Ao analisar o anúncio da edição de 2007 (imagem 2), é possível verificar toda a mobilização das redes de relações sociais, dos atletas externos, patrocinados, no lançamento de modelos de shapes, e do patrimônio da família, já que foi realizado no Freitas Park.

Imagem 2 - Anúncio do QIX

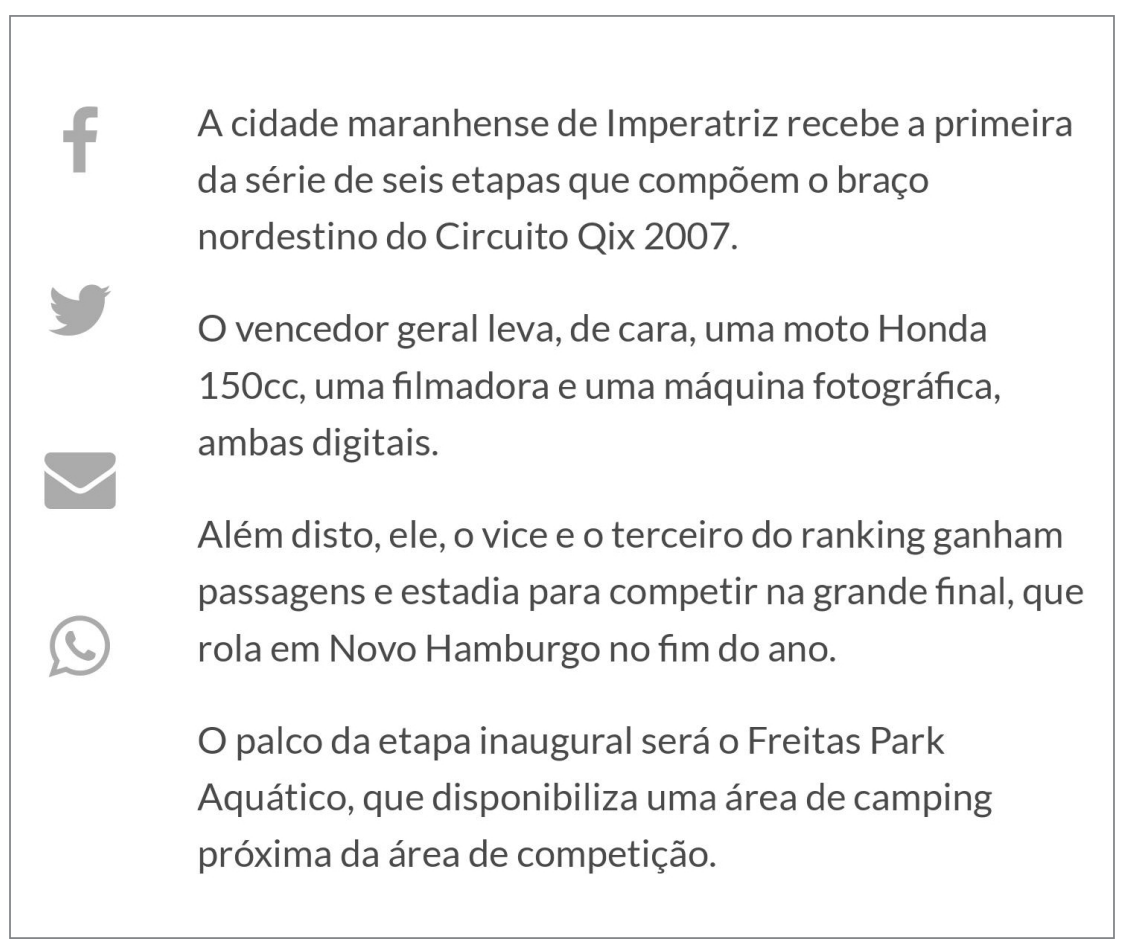

Fonte: Disponível em: <https://triboskate.ativo.com/noticias/circuito-qix-nordestino/>. Acesso em: 19 nov. 2019.

Enfim, longe de se tratar de um ambiente de vagabundos ou drogados, como afirmavam os três entrevistados quando se referiam aos estigmas sofridos por conta da prática do skate, a observação da trajetória desses três atores sociais vinculados à Go Skateboard mostra um trabalho coletivo e a mobilização de vários recursos para a construção de uma ideia de profissionalização da prática do skate por meio da inserção dela ao mercado de peças e assessórios relacionados 
ao estilo street. Quando se comenta sobre perfil empreendedor do esporte, Divino Noleto Freitas explica: “Tem todo um mercado por trás. Tem fábricas de skate, tem fábrica de tênis, tem fábrica de shape de rodinha. É como futebol, tem os times de futebol, né, e tem os patrocínios" (Freitas, Divino Junior, entrevista realizada em 04/03/2017, grifos nossos).

Assim, tanto as primeiras representações estigmatizadas por conta da Praça Mané Garrincha quanto a sua oposição focada no glamour do esportista do skate que é financiado, defensor de uma estética e modo de vida, podem ser compreendidos como os primeiros obstáculos epistemológicos (Bachelard, 1996) da pesquisa. Assim, foi necessário um exercício de geometrização e retomada de questões centrais para a sociologia, como não explorar a juventude, por exemplo, focando não apenas nas similaridades entre os jovens, mas também nas diferenças (Pais, 1990).

Nesse sentido, autores como Bourdieu (1983), Novaes (2006), entre outros, explicitam a importância de não se tomar a "juventude" e outras categorias de classificação (de idade) como um dado, e de tomá-la como definição em disputa como construção histórica e social. Também no mesmo caminho de desnaturalização das primeiras noções, Feixa (2004) toma esse problema sociológico em termos de "cultura juvenil", compreendendo-a como "a maneira como as experiências sociais dos jovens são expressas coletivamente por meio de determinados estilos de vida que têm como referência o tempo livre". Magnani (2012) percebe o problema no viés da construção de identidades, estratégias, da experiência cotidiana dos atores sociais e do lazer. No caso da presente pesquisa, o ponto a ser problematizado é a questão do lazer, já que o skate analisado em Imperatriz passou por um processo de esportivização e profissionalização vinculado às lógicas do mercado.

\section{A equipe da Hard Flip: um giro forte}

Um ano antes do surgimento Go Skateboard já existia a marca Hard Flip, em 2002, em Imperatriz. Além dos shapes, a empresa também fabricava as rodinhas e o trucks que compõem o skate. Segundo Claudio da Silva Pereira, também conhecido como Cláudio Secco, o nome da marca significa "giro duro", título de uma manobra difícil no mundo do skate e que, em termos de marketing, tem uma expressão que representa a marca. De modo sintetizado, Cláudio Secco tem 45 anos, é um skatista e empresário que veio de Dom Pedro, localizada a $435 \mathrm{~km}$ de Imperatriz. Ele chegou na cidade com 7 anos e é um dos praticantes mais veteranos atualmente. 
Ele iniciou nesse esporte entre 1986 e 1987, e viu o primeiro skate em uma loja de Imperatriz-MA. Contudo, só obteve o primeiro graças a uma troca que fez entre um skate de um amigo e seis fitas de videogame Atari, que, na década de 1980, era uma diversão muito moderna e de ponta. Inclusive, o entrevistado relatou que inicialmente compreendia o skate como outro tipo de brinquedo.

Ele foi gerente da loja Gringo Skate Wear no início da década de 1990, comércio que Junior Freitas conheceu na condição de consumidor e jovem em processo de integração com o skate local. Para compreender a importância dessa loja no processo de sociabilidade entre os skatistas, basta recordar que além de ser a única da época a fornecer equipamentos e informações relacionadas a esse mundo, foi a que promoveu o primeiro campeonato da cidade.

Imagem $3-1^{\circ}$ campeonato de skate em Itz

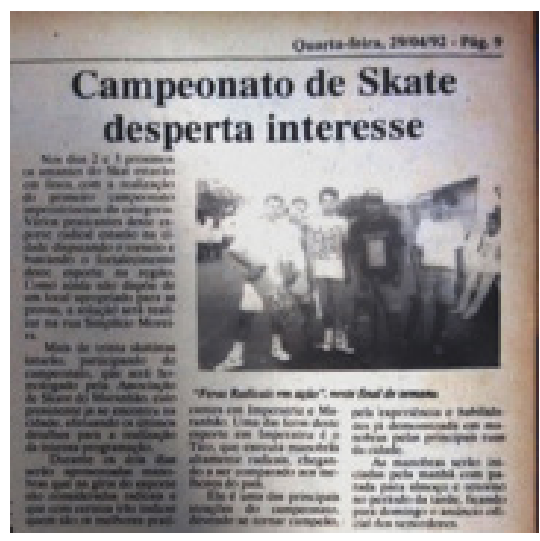

Fonte: Arquivo do autor, 2018.
Imagem 4 - Troféu do campeonato

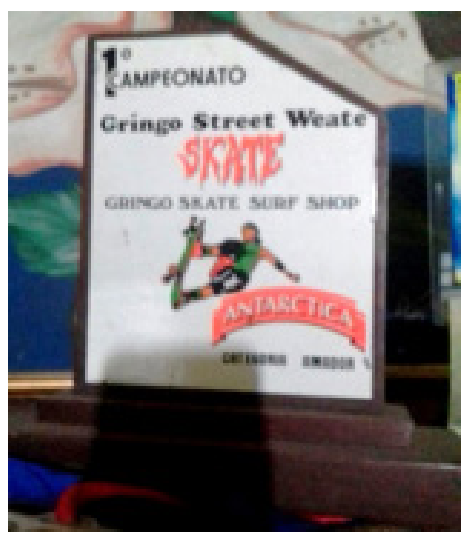

Fonte: Arquivo pessoal de "Cláudio Secco"

Segundo reportagem do jornal o Progresso (29/04/1992), o campeonato imperatrizense foi realizado entre os dias 2 e 3 de maio de 1992, na rua Simplício Moreira, já que a cidade ainda não possuía skatepark na época, e contava com uma previsão de participação de mais de 30 skatistas. Um dos destaques dados na matéria é para o skatista Tico, que executava "manobras altamente radicais". Tico, que se chama Francisco Admael de Souza Costa, residia no centro da cidade, e é considerado pelos donos das duas marcas analisadas aqui como um dos pioneiros no skate local, juntamente com outros jovens conhecidos como "Rato" "Largato" e "Faraó" 10. Cláudio relatou que assim que obteve um skate teve

10 Desses primeiros, obtive contato com o Francisco Admael de Souza Costa (Tico) e Francisco Marcelo Correia (Faraó), ambos com 45 anos, que residiam no centro da cidade e que ingressaram no skate com 17 
contato com esses primeiros skatistas e com outros que andavam no centro da cidade. Assim, o princípio do movimento em Imperatriz estava atrelado a esse primeiro núcleo de cinco jovens.

Retornando a trajetória profissional de Cláudio e o surgimento da marca Hard Flip, é importante considerar que em meados de 1994 foi proprietário da Bando Street Wear, o que lhe possibilitou mais contato com os fornecedores de peças de São Paulo. A loja durou seis anos e, após essa experiência, Cláudio ficou "parado" por dois anos, até observar que estava começando a surgir uma demanda por peças. Segundo ele, essa demanda por peças e equipamentos foi um dos motivos para o surgimento da Hard Flip. Já para este estudo, é resultado de todo o acúmulo de experiência desse ator social e mobilização de uma rede mais ampla de jovens skatistas.

Nesse sentido, embora o skatista-empresário tenha uma trajetória que lhe garanta respeito no meio dos jovens praticantes desse esporte, é necessário explicitar que a existência da marca também resulta de outros trabalhos e atores engajados. Assim, é importante enfatizar que na referida empresa há uma divisão do trabalho bem definida na qual o Claudio da Silva é o proprietário, patrocinador e veterano no skate; Aldermar Coelho da Silva era o atleta da marca, Audierio Marinho o responsável por encontrar novos atletas e produzir vídeos das manobras em vários cantos da cidade, ou o Team Manager, como define o próprio empresário.

Audierio Marinho foi o primeiro contato obtido com os skatistas engajados na Hard Flip. Ele tem 33 anos e pratica skate desde novembro de 2000, quando tinha16 anos. Reside com os pais no bairro dos Três Poderes e diz que obteve os dois primeiros skates dando em troca uma gameshark de plastation $1^{11}$ para um amigo. Sobre a integração dele com o skate street e com o mercado, ele explica:

Um amigo meu lá perto de casa que andava de skate me influenciou muito a andar e continuar andando de skate, que é o Branquelo. Das antigas tem o Cláudio Secco, que ele é até Dono da Hard Flip. Eu mesmo já conheci

anos em um período anterior aos tempos de inserção de "Junior" e "Claudio Secco". Tico relatou que ele e "Lagarto" tiveram contato o skate por meio de um primo paulista de "Lagarto" que trouxe a novidade para Imperatriz-MA. Já Faraó recorda que o primeiro contato que teve foi graças ao Tico, que o levou para mostrar o "novo" esporte. Esses foram os primeiros processos de socialização e de formação dos primeiros jovens da cidade que realizavam o skate street.

11 Trata-se de um acessório que era acoplado no videogame Playstation 1 produzido pela Sony. O entrevistado relata que, embora tivesse um gameshark, não possuía um Playstation e que só foi obter um quando começou a trabalhar e ganhar o próprio dinheiro. Com o gameshark, é possível trapaçar nos jogos e obter vidas infinitas e outras vantagens para os personagens dos jogos. 
logo o dono dessa marca, daí eu já fui aprendendo com ele, aprendendo o que é peça boa. Inclusive eu to produzindo essa Marca há mais de dez anos. E eu fui fazendo marketing e aprendendo, vendendo e influenciando (Marinho, Audierio entrevista realizada em 10/03/2017, grifos nossos).

Dessas sociabilidades com o amigo Aldemar Coelho da Silva, também conhecido como Branquelo, Audierio se projetou em um processo de integração com o skate que o colocou como um dos mais ativos da marca Hard Flip, possuindo um papel similar ao "Japa" no processo de inserção na marca concorrente.

Nesse sentido, observamos que, no ano de 2004, a Hard Flip montou uma pista em um galpão no bairro do Maranhão Novo. Assim como a pista da marca concorrente, construída três anos depois no Freitas Park, é importante salientar que tais investimentos possibilitavam uma experiência de skatepark que até então era desconhecida na cidade, pois mesmo que a Praça Mané Garrincha já existisse na época, ela ainda não possuía um conjunto de rampas e equipamentos especializados para o desenvolvimento das manobras de skate.

Nessa pista do Maranhão Novo, a escala de trabalho era organizada da seguinte maneira: Audierio cuidava dela durante a semana, e nos fins de semana ficavam "Cláudio Secco" e um "atleta da marca" chamado Douglas. Segundo o empresário, houve uma tentativa de boicote por parte das pessoas que não desejavam a evolução dele, nem do próprio esporte. Ele ressalta que, associado a isso, poucas pessoas pagavam para utilizar a pista, ocasionando prejuízo e incapacidade de pagar o aluguel de $\mathrm{R} \$ 600,00$ mensais. Dessa maneira, uma das ações (estratégicas) adotadas, antes de decidir fechar o empreendimento, foi a promoção de um campeonato que ficou como último fato ocorrido na pista.

Além da organização do trabalho, que era uma constante na formação da Hard Flip, algo que chamou a atenção foi a tensão em torno da pista, ou seja, o movimento de "boicote" que surgiu no universo dos próprios skatistas da cidade. Segundo Cláudio Secco, uma das principais acusações seria de que "ele estava querendo ganhar dinheiro", uma classificação que difundia uma ideia que reforçava o papel de empresário e diminuía o papel de skatista, na medida em que buscava atribuir uma motivação econômica e não de afeto, prazer e emoção, ou da prática do skate com filosofia de vida.

É importante considerar que se tratava de primeira pista privada instalada na cidade e que, até então, a prática do skate se desenvolvia nas ruas e em obstáculos caseiros produzidos ou confeccionados em serrarias locais, que eram 
socializados entre os jovens skatistas. Dessa maneira, é possível considerar um antagonismo entre a liberdade do skate street e o condicionamento econômico da pista. Na primeira concepção, a ideia é de lazer e explorar os espaços da cidade, na segunda percepção, há um intuito de preparação competitiva para campeonatos, demonstrando, assim, estruturalmente, um momento de tensão e transição.

Tal contexto é importante para compreender os aspectos estruturais que podem auxiliar na resistência do grupo em pagar pelo uso do espaço. Somado a esse contexto, os papéis de empresário e skatista assumidos por Cláudio são atacados, segundo o entrevistado, com vistas a prejudicar a constituição de um status de skatista. Pode se destacar que o enquadramento feito sobre a representação da pista do Maranhão Novo ocorre por conta da manipulação de informações dos bastidores da sua produção, ou seja, os antagonistas enfatizam o que deveria ser ocultado ou ficar em segundo plano. Sobre isso, Goffman (2013: 55) explica que "o ator pode estar empenhado em uma forma lucrativa de atividade que aculta de seu público por ser incompatível com a noção dessa atividade que ele espera que o público tenha". Quando se indaga para um ex-atleta da marca sobre o contexto da pista, ele explica:

Teve a pista do Maranhão novo e o Junior também tinha uma. Aí era aquela coisa... Era a época em que era meio dividido o Skate em Imperatriz e graças a Deus acabou isso, hoje em dia todo mundo se fala normal. E essas desavenças era mais assim porque quem não usava falava mal de quem usava e quem usava falava mal de quem não usava. Então deixamos quietos e não nos juntamos não, deixa do jeito que ta (Silva, Aldermar Coelho, entrevista realizada em 10/04/2017, grifos nossos).

Reforçando a ideia da existência de tensão entre as duas equipes, o relato conforma a divisão entre skatistas e que a opção da equipe Hard Flip foi de não se juntar com os antagonistas. Por mais retórico que pareça, tal conflito possui uma função de reforço na identidade da marca, ou seja, quando situamos as duas marcas e se pergunta "quem será que usava?" e "quem será que não usava e criticava quem usava?", significa que está ocorrendo uma clara definição de diferentes projetos, e construção de identidade por meio da oposição dos grupos.

Assim, se até agora se estava analisando a formação das marcas em relação às divisões do trabalho e processos de sociabilidades entre os membros, não se pode desconsiderar as tensões e a função social delas, pois, como percebe Simmel (1983), o conflito também possui uma função sociológica de afirmação das unidades. Seguindo o viés da interação, o 
clássico explica que "as relações de conflito, por si mesmas, não produzem uma estrutura social, mas somente em cooperação com forças unificadoras. Só as duas juntas constituem o grupo como uma unidade viva e concreta (Simmel, 1983: 128). Assim, por esse viés, tais marcas teriam um caminho a trilhar para a formação de unidades (com mais consenso) com o auxílio da situação de concorrência e conflito, por um lado, e do trabalho aglutinador de suas lideranças, por outro. Mais adiante, será explicado que não se trata apenas de uma disputa de mercado, mas que todas as diferenças sociais e de conduta serão postas nessa arena de conflito.

Atualmente, em ambas as marcas, os membros possuem uma visão acerca do skate que distoa daquela, mais antiga no senso comum, que os toma como desocupados e indeliquentes; e também da veiculada nos meios de comunicação, que valorizam apenas o lado do entreterimento. O próprio Audiério explica que "Não é só algo legal, radical e doido, não. É algo que tem uma cultura, que sustenta famílias, é algo que gera negócios e rendas em um país. Gera impostos (Marinho, Audierio entrevista realizada em 10/03/2017, grifos nossos). Quando se considera a tensão por conta da cobrança do uso da pista em 2004 e a explicação de Audiério, percebemo-lo como um agente que busca conciliar os papéis de esporte e mercado empresarial em torno do skate, por meio do alinhamento das ideias de trabalho, família e obtenção de renda, desmobilizando qualquer versão pejorativa sobre quem "estiver querendo ganhar dinheiro" inserindo-se no esporte. Trata-se de uma ação que reafirma o pertencimento desse ator social, já que, como nota Goffman (2013), um membro da equipe é alguém cuja cooperação dramatúrgica contribui para manter uma dada definição de situação diante da plateia.

Nos meses em que foi realizado o trabalho de campo, foi possível ter a oportunidade de acompanhar o trabalho de Audierio na produção (imagem 5) de um jovem skatista chamado Alex Chabunas, que na época estava nesse processo de integração com a marca Hard Flip. Assim, a tarde do dia 26 de março foi marcada pelo deslocamento até a escadaria da passarela localizada na BR 010, conhecida como Belém-Brasília, onde foi realizada a gravação de um vídeo ${ }^{12}$, no qual Alex faria um Hard Flip. Após encostar as bicicletas juntas no canto da barreira de proteção que separa a BR da MA, foram escolhidos ângulos privilegiados para captar as manobras do jovem skatista.

12 O vídeo pode ser acessado no link disponível em: <https://www.youtube.com/watch?v=xzauboOhyco $>$. Acesso em: 11 set. 2019. 
Imagem 5 - Audierio no trabalho de produção visual para a Hard Flip

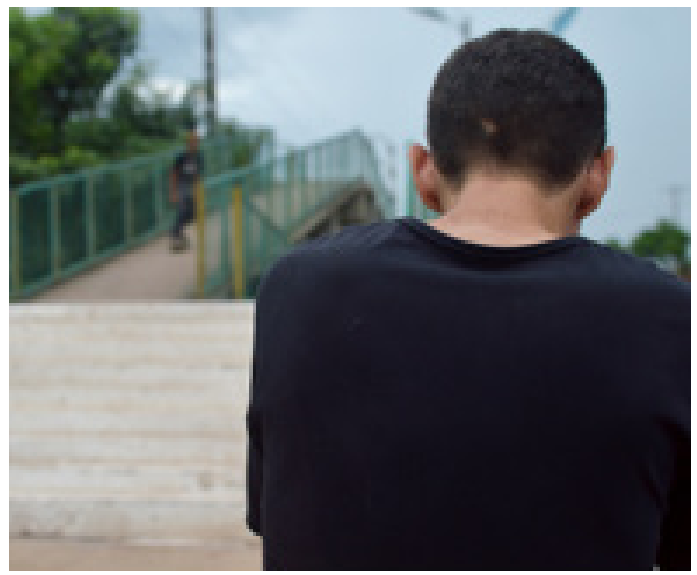

Fonte: Autor, 2017

Além da produção, ele também alimenta um canal de vídeo no YouTube ${ }^{13} \mathrm{com}$ vários outros que mostram os atletas da Hard Flip fazendo manobras no skatepark na Praça Mané Garrincha e nos principais picos da cidade, ou seja, os locais com mais declives, escadarias ou qualquer outro que favoreça o desenvolvimento das manobras. Notou-se, assim, que esse trabalho de comunicação e marketing em favor da referida marca constitui um canal de difusão de uma estética global (Diogenes, 1998) materializada não apenas nos equipamentos em si, mas na forma de se vestir, na expressão corporal e em uma relação específica de interação com a cidade.

Além desse trabalho de promoção de visibilidade, observou-se a presença dele na Praça Mané Garrincha, local onde ele observa e faz contato com os jovens skatistas que possuem alguma habilidade diferenciada que possa potencializar a marca. Sobre o engajamento de Audierio, um ex-atleta da marca e amigo dele comenta: "O Audierio sempre foi o Team manager da Marca, ele é um cara que foi patrocinado desde o início mesmo sem saber andar, mas pelo fato de ser amigos de todos e tal" (Silva, Aldermar Coelho, entrevista realizada em 10/04/2017, grifos nossos).

Pode-se dizer que esse ator social faz um importante papel de mediação entre proprietário da Hard Flip e os "novos talentos" e quaisquer outros atores que possam beneficiar a marca. A relação entre eles traz aspectos de um conjunto de ação atrelado a conjuntos de status e papeis,

13 Disponível em: <https://www.youtube.com/channel/UCYgo5CoRXSkZRDC8msZAsgg>. Acesso em: 11 set. 2019. 
Pois, como o ego, a pessoa detém um conjunto de papéis composto pelas relações mantidas com os intermediários e respondentes terminais; e, como intermediário, detém um conjunto de papéis diferentes ante o ego, o respondente e, eventualmente, outros intermediários. Em nível diferente, ego e seus intermediários, de um lado, e intermediários e respondentes, de outro, acham-se articulados por papéis escolhidos de seus respectivos conjuntos de status (Mayer, 2010: 169).

Tais conjuntos de status e papéis são importantes quando visualizamos, mentalmente, Cláudio como proprietário e skatista tendo que desenvolver um controle de impressões com autoridades públicas, como foi o caso do diálogo com membros da administração pública para a promoção de eventos de skate na Praça Mané Garrincha, mas ao mesmo tempo dialogando com diferentes gerações, e relacionando-se profissionalmente e amistosamente com Audiério, que, por sua vez, atua como um importante intermediário ${ }^{14}$ que faz uso da popularidade para ampliar a rede de relações interpessoais para além do conjunto de atores da Hard Flip. Na outra ponta do processo, Alex da Costa Chabunas, de 16 anos, que pratica skate há dois anos e diz que participou de dois campeonatos e de uma sessions15, quando depois foi convidado a participar da Hard Flip, e atualmente busca uma profissionalização cada vez maior no esporte.

É interessante destacar que, nessa etapa da esportivização, o processo de sociabilidade é distinto daqueles praticados na época inicial, quando os jovens se conheciam nas ruas. No âmbito da Hard Flip, pode-se citar o ex-skatista Aldemar Coelho da Silva (conhecido como Branquelo), de 33 anos, que morava no Maranhão Novo, próximo de Audiério, de quem era amigo. Branquelo andou de skate dos 16 até os 23 anos, foi o terceiro ${ }^{16}$ atleta da Hard Flip, e teve contato com Claudio Secco por conta do skate street, já que naquela época ainda não existia o skatepark da Praça Mané Garrincha.

Enfim, o conjunto de indivíduos constituído em torno de "Cláudio Secco" apresentava características sociais mais homogêneas, pois os integrantes do núcleo inicial eram todos da região central ou próxima ao centro da cidade. Com características distintas, a liderança do grupo teve que se valer de uma

14 No caso atual da Go SkateBoard, "Japa" concentra as funções de divulgação, fabricação de shapes sob encomenda e contato com jovens skatistas.

15 São encontros de skatistas, nos quais os jovens executam as manobras e os patrocinadores e jurados ficam observando e os classificando. É um importante lugar para a integração entre jovens skatistas e patrocinadores.

16 Antes dele, o primeiro foi o Ivanilson Lima de Souza (conhecido como Kioday) e Marquinhos (não foi possível encontrar o nome real). 
estratégia de conciliar os investimentos na fabricação de shapes com as atividades empresariais de venda de peças, promoção de eventos, entre outras.

Sobre os campeonatos, observou-se que, no dia 8 de outubro de 1997, houve a reinauguração da Praça Mané Garrincha com a construção das mini-rampas para a prática do skate. Sobre o evento, o Jornal Capital (15/10/1997: 6) traz a narrativa a respeito de uma programação vasta de várias modalidades esportivas e descreve: "Na apresentação de skate, o garoto Cláudio recebeu o título de melhor atleta na categoria Mini-ramp". Já entre os dias 23 e 25 de novembro ocorreu o campeonato Rei do Nordeste, em Imperatriz. Embora os jornais e blogs ${ }^{17}$ afirmem que a promoção foi de Cláudio Secco e Leonardo Carioca, em diálogo com Cláudio Secco, soube-se que a reta final da produção do evento foi desenvolvida apenas por Leonardo Carioca. Na divulgação do evento, obtida de um blog especializado no esporte, encontra-se a seguinte informação a respeito do histórico do esporte em Imperatriz:

O skate Imperatrizense tem raízes fortes desde a década de 90, através dos skatistas pioneiros "Tico Or Die, Marcelo Faraó, Largarto e Cláudio Secco", sendo um dos únicos a permanecer na ativa competindo e fazendo com que o esporte cresça. ${ }^{18}$
Atualmente Leonardo da Paz "Carioca" e Claudio Secco se encontram dentro do esporte não só como atletas, mas como empresários no mun- do do skate, pois os mesmos são fabricantes de shape, considerado a alma do skate, já que a peça é primordial para a prática do mesmo. (...) Imperatriz também foi palco para duas competições a nível nacional, com competidores de todo o país que pode ser visto na internet, que ocorreu no ano de 2008 e 2009 no Freitas Park, que foi idealizada pelo skatista Junior Freitas e patrocinada pela empresa fabricante de tênis QIX IN- TERNACIONAL, uma das mais conceituadas marcas de skate no país (En- contros radicais, 2012 $2^{19}$ ).

\footnotetext{
17 Disponível em: <http://oprogressonet.com/esporte/sedel-promove-torneio-de-skate-na-reinauguracao-da-pista-da-praca-mane-garrincha/12974.html>. Acesso em: 11 set. 2019.

18 Segundo os relatos coletados e algumas observações diretas, obteve-se a informação de que "Rato" envolveu-se com o crime e mudou-se para Palmas; "Lagarto", apesar de ter falecido por conta de complicações ocasionadas pela diabetes, também teve o nome vinculado ao crime. Os outros dois restantes, ainda vivos, trafegam pela cidade e possuem envolvimento com o consumo de drogas. Dessa forma, das primeiras referências, o único que se mantém até hoje na prática e afastado das práticas ilícitas é o Cláudio Secco. É possível que o estigma mais geral construído em relação aos skatistas da praça possa ter alguma relação com essa primeira geração desviada (Becker, 2008).

19 Disponível em: <https://encontrodosradicais.blogspot.com/2012/10/no-post-logo-em-baixo-boa-noticia-sobre.html>. Acesso em: 11 set. 2019.
} 
Algo que chamou atenção é que, no histórico do esporte publicizado no evento de divulgação do campeonato, a empresa Go Skateboard, já como propriedade do "Japa", não aparece no histórico. A narrativa reforça a experiência do veterano da Hard Flip e o cita, juntamente com Leonardo Carioca (StreetCity Skateboading), como únicos fabricantes de shape na cidade. O campeonato Qix Nordeste, promovido pela Go Skateboard, é desvinculado da marca e atribuído a Junior Freitas, que já não era mais proprietário dela. Enfim, a narrativa traz uma lógica de ênfase de alguns aspectos e ocultamento de outros que caracteriza bem a tensão entre as marcas. Após essa constatação, verificou-se no anúncio do QIX de 2008 que a Hard Flip, apesar de ser a marca mais antiga de shapes em Imperatriz-MA, não estava na promoção do maior evento realizado na cidade. Considerando a observação das relações entre as duas equipes, não é de se estranhar tais fatos.

Imagem 5- QIX 2008 e as estratégias de ocultamento e ênfase

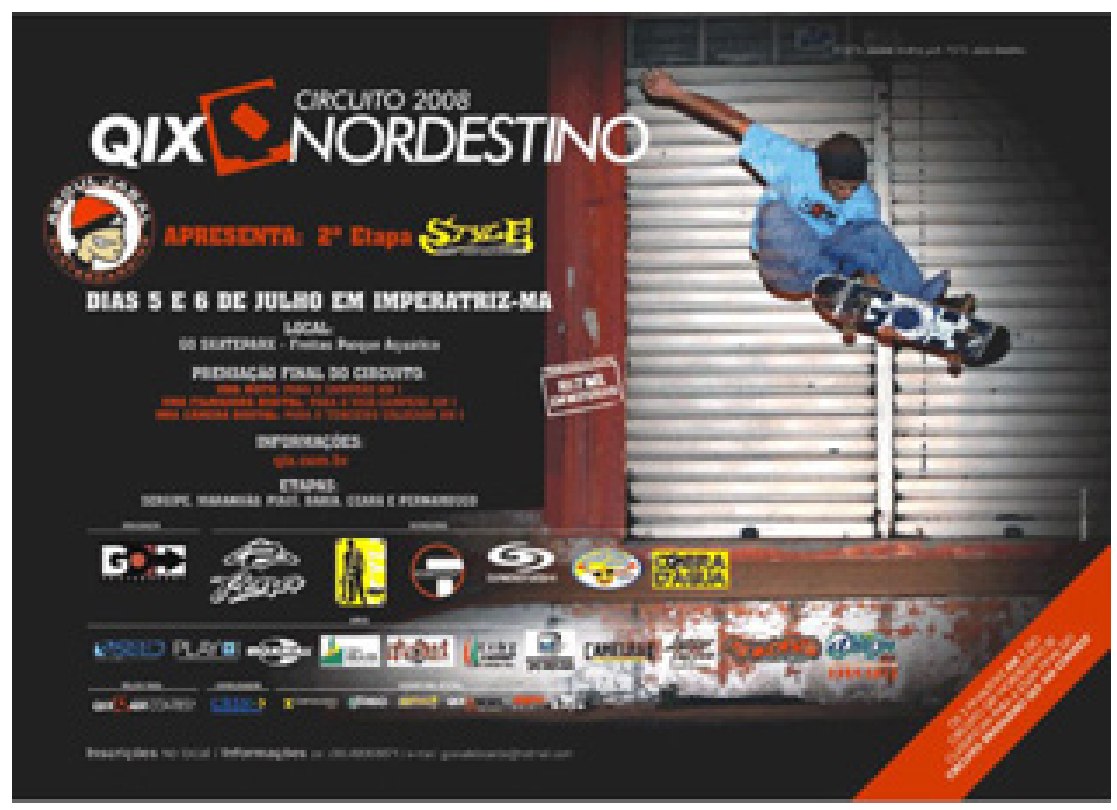

Fonte: Acervo do autor, 2017

O conhecimento prévio sobre alguns membros das duas marcas gerou um afastamento total da ideia de skate relacionado, exclusivamente, ao lazer da "juventude" e aos estigmas lançados sobre a Praça Mané Garrincha, ou sobre os jovens skatistas. Longe de ser apenas lazer, há uma lógica empresarial por meio da qual se pode delinear as tensões entre as marcas e o próprio processo 
de esportivização (Brandâo, 2008) do skate em Imperatriz. Os silenciamentos, ocultamentos e determinadas ênfases apontam para a delimitação de fronteiras e tensões entre esses conjuntos de atores sociais.

Antes de seguir, algo que deve ser explicitado é que, no primeiro conjunto analisado (Go Skateboard), o primeiro proprietário tinha um monopólio de capitais que possibilitava uma boa especialização e ressaltavam indiretamente as diferenças entre os membros da equipe, inclusive por conta das formas de sociabilidade, locais de moradia (distantes e em diferentes bairros), papel e inserção na marca. Já o segundo (Hard Flip) apresenta características mais homogêneas, alguns casos de relações de vizinhanças que antecedem a inserção no skate e uma estratégia mais ancorada nos capitais sociais, e menos no econômico. Uma situação emblemática que representa isso foi obtida com o relato de Cláudio Secco:

Ninguém sabia nada, não tinha internet não tinha divulgação. Tudo era em revistas. O Tico viajou pra Belém, lá o fluxo era maior daí ele já trouxe mais manobras. Porque na realidade a gente via o cara parado no ar numa foto, então via o nome e tentava analisar que tipo de manobra era. Cara, muito difícil. Hoje em dia não, tem slow-motion, tem net, tem tudo. Por isso que a nossa evolução em Imperatriz demorou a acontecer. Tudo que a gente das antigas aprendemos foi na rua (Pereira, Claudio da Silva. Entrevista realizada em 10/03/2017, grifos nossos).

Assim, a ausência do videocassete para facilitar o aprendizado das manobras, mais que uma simples ausência de recurso, sinaliza um elemento de distinção clara entre as duas histórias e demonstra os diferentes caminhos e estratégias adotados pelos skatistas empresários.

Já uma característica comum nos dois conjuntos de atores foi a centralização de todos os membros em torno dos dois skatistas e empresários proprietários das duas marcas, que se constituíam como os focos organizadores de tudo. Por tal aspecto, seria possível pensar tais ajuntamentos como um conjunto (Mayer, 2010), orientado em torno de dois egos. Por outro lado, é importante lembrar que também se agrupam em função de interesses comuns e no contexto da execução de determinadas atividades relacionadas ao mundo do skate. No âmbito das interações, também podem ser pensados como equipes já que

pode ser definida como um conjunto de indivíduos cuja íntima cooperação é necessária para ser mantida uma determinada definição projetada de situação. Uma equipe é um grupo, mas não um grupo em relação a uma 


\section{estrutura ou organização social, e sim em relação a uma interação, ou} série de interações, na qual é mantida a definição apropriada de situação (Goffman, 2013: 118).

Enfim, a análise do skate com base nas interações e nos papéis desenvolvidos acerca das projeções de cada conjunto de atores, podemos observar continuidades entre as experiências de vida e itinerários dos jovens skatistas. Como percebe Frúgoli (2007) e Hannerz (2015), é possível pensar a cidade como teatro, já que é nos espaços urbanos que se costuma afluir os diferentes grupos.

Explicando a abordagem Goffmaniana, Hannerz (2015) diz-se-ia que no processo de construção dessa fachada e das representações em torno do skate podem ser pensados em termos de palco e bastidores, pois, para o pensamento de Goffman (2013), ocorreria um processo de ocultamento dos conflitos e falhas nas representações para a apresentação de um "produto final". Um ponto de partida para a compreensão dos bastidores que não são visíveis para o público de observadores de primeira viagem foi o de buscar as condições estruturais e os processos relacionados às interações, ou seja, não focar apenas na interação em si, mas nas experiências dos participantes e como eles interpretam a situação de participação (Nunes, 1993).

Percebemos que a reprodução social do skate se forja em unidades compostas com base nas mais diversas relações (amizade, trabalho, admiração, reciprocidade etc.) em torno das lideranças das marcas, caracterizando um conjunto cuja organização, os papéis e os status são direcionados de acordo com os "egos". Ela ocorre quando os conjuntos de indivíduos passam a interagir entre si em busca de certas finalidades e interesses, produzindo as sociabilidades que fazem com que os agregados de indivíduos ganhem forma nas relações entre si (Simmel, 2006). Assim, é possível pensar na associação de jovens skatistas em direção aos núcleos dos grupos.

Uma vez que cada tipo de relação traz consigo as mais diversas experiências, os enquadramentos e contra-enquadramentos construídos nas relações entre os dois conjuntos de atores acaba formando um jogo de oposições. Nesse sentido, membros de um conjunto se colocam totalmente contra os usos de maconha e drogas, citando também uma divisão entre "os que usam" e "os que não usam", enquanto membros de outro grupo entendem a maconha como uma droga leve comum no mundo do rock e do skate, possibilitando-nos compreender um processo de enquadramento direto do grupo A sobre o grupo $\mathrm{B}^{20}$. A questão da

20 Para evitar conflitos diretos e constrangimentos, optamos por não identificar os entrevistados. 
condição econômica e patrimônio familiar também foi outro ponto observado nas tentativas de construção de diferenciação: enquanto membros de um grupo enfatizam a dificuldade e ressaltam a condição econômica privilegiada, os membros mais abastados enfatizam a simplicidade aprendida no mundo das ruas graças ao skate. Dessa forma, mesmo sem citar nomes, as interpretações sempre estavam direcionadas, e o trabalho de pesquisa parecia ser um tipo de elo entre as diferentes versões.

Por outro lado, observa-se que o trabalho social caracterizado na promoção de campeonatos, na valorização das marcas locais, na difusão de vídeos, na mobilização de recursos e de redes de relações interpessoais foram fundamentais na construção de uma visibilidade pública para o skate. Atrelado a isso, há a construção e difusão de um discurso focado no esporte, e não apenas no lazer. Por outro lado, parafraseando Berger (2011), tais atividades reforçam um conjunto de hábitos por meio da repetição, ao longo dos anos. Trata-se, também, de um caminho favorável à institucionalização do skate, já que a repetição de um hábito estimula a direção para a especialização de pessoas na área, e passa a gerar significados para os jovens que se integravam naquele meio.

\section{Considerações finais}

O contato mais próximo desconstruiu uma visão totalizante e estigmatizante que toma os skatistas como irresponsáveis, vagabundos ou drogados. Ao acompanhar a trajetória de alguns atores sociais desse meio, foi possível se deparar com um trabalho social que tem sido desenvolvido desde a década de 1990, acerca da promoção da prática do skate. Tem-se, assim, importantes aspectos de uma história social, ou seja, de um movimento temporal movido por interações de atores sociais que possibilitaram a construção de uma definição de skate na cidade.

Da época da preponderância dos praticantes do skate de rua (streeteiros) até o atual período em que a profissionalização e o skate park estão marcados na cidade, inclusive na Praça Mané Garrincha, verificou-se um longo percurso marcado por itinerários e sociabilidades que demonstram o processo de institucionalização da prática do skate na sociedade Imperatrizense. As ruas, as pistas e a praça aparecem como lugares comuns nos processos de sociabilidade das três gerações. Espaços de encontro de histórias da vida, de expectativas de transmissão de saberes, de conflito e aglutinação dos atores em torno das marcas. Fosse por amizade, pela relação profissional ou pela relação de vizinhança, constitui-se uma série de processos sociais de cooperação e conflito que foi 
fundamental na construção dos conjuntos de atores em torno das marcas, ou dos egos. Por conta disso, as relações entre os egos e os intermediários são marcadas pela mobilização de vários papéis e status.

Embora os conjuntos não possuam um contato direto para a construção de um diálogo a respeito da classificação comum do total de skatistas ou entre si, as classificações e interpretações que fazem de si próprios quase sempre apontam para as características do concorrente, demonstrando a existência de um campo de relações, uma espécie de arena invisível aos olhos mais distraídos, mas perceptível nos detalhes expressos na forma como se apresentam.

Funcionando como uma microsociedade, a comunidade do skate em Imperatriz é caracterizada pela disputa de narrativas históricas sobre a fabricação de shapes, marcada por disputas que podem ser percebidas em silenciamentos e ocultmentos com capacidade de delimitar as fronteiras dos conjuntos de atores. O palco e os bastidores são pontos por meio dos quais foi possível notar que a esportivização do skate também significou uma tensão entre os papéis de empresário e skatista, que com o tempo e auxílio da equipe foi solucionada graças ao empenho dos membros, principalmente desde o início da década passada.

\section{Referências}

AGIER, Michel. Antropologia da cidade: lugares, situações, movimentos. São Paulo, Editora Terceiro Nome, 2011.

ADERALDO, Guilhermo. Reinventando a "idade": uma etnografia das lutas simbólicas entre coletivos culturais vídeo-ativistas nas periferias de São Paulo. São Paulo, Annablume, 2017.

BACHELARD, Gaston. A formação do Espírito Científico: contribuição para uma psicanálise do conhecimento. Rio de Janeiro, Contraponto, 1996.

BERGER, Peter, LUCKMANN, Thomas. A construção social da realidade: tratado de sociologia do conhecimento. 33 ed. Petrópolis, RJ, Vozes, 2011.

BOISSEVAIN, Jeremy. Apresentando "amigos de amigos: redes sociais, manipuladores e coalizões". In: FELDMAN-BIANCO, Bela (org.). Antropologia das sociedades contemporâneas. São Paulo, Editora UNESP, 2010, pp. 205-235.

BOURDIEU, Pierre. A juventude" é apenas uma palavra. In: Questões de sociologia. Rio de Janeiro, Marco Zero, 1983, pp. 112-121.

. "O capital social: notas provisórias" In: NOGUEIRA, Maria Alice; CATANI, Afrânio. Escritos de educação. Rio de Janeiro, Vozes, 2001.

BRANDÃO, Leonardo. A Cidade e a tribo skatista: juventude, cotidiano e práticas corporais na história cultural. Dourados, Ed. UFGD, 2011, p. 160. 
BRANDÃO, Leonardo. Entre a marginalização e a esportivização: elementos para uma história da juventude skatista no Brasil. Recorde: revista de história de esporte, Rio de Janeiro, v. 1, n. 2, pp. 01-24. dez. 2008. Disponível em: <http://www.sport.ifcs. ufrj.br/recorde/pdf/recordeV1N2_2008_15.pdf>. Acesso em: 31 maio. 2012.

DAYRELL, Juarez. O jovem como sujeito social. Rev. Bras. Educ. [online]. 2003, n. 24, pp. 40-52.

DIÓGENES, Glória. Cartografias da cultura e da violência: gangues, galeras e o movimento Hip Hop. São Paulo, Annablume; Fortaleza: Secretária da Cultura e Desporto, 1998.

ECKERT, Cornelia; ROCHA, Ana Luiza Carvalho. Etnografia de rua: estudo de antropologia urbana. Revista Iluminuras, v. 4, n. 7, 2003.

FRÚGOLI JUNIOR, Heitor. Sociabilidade urbana. Rio de Janeiro, Jorge Zahar Ed, 2007.

GOFFMAN, Erving. Comportamentos em Lugares Públicos - Nota sobre a organização social dos ajuntamentos. Petrópolis, RJ, Vozes, 2010.

GOFFMAN, Erving. A representação do eu na vida cotidiana. Trad. de Maria Célia Campos Raposo. 20. ed. Petrópolis, RJ, Vozes, 2013.

HANNERZ, Ulf. Explorando a cidade: em busca de uma antropologia urbana. Petrópolis, RJ, Vozes, 2015.

LENOIR Remi. "Objeto sociológico e problema social”, Objeto sociológico e problema social. In: CHAMPAGNE, Patrick; LENOIR, Remir; MERLLIÉ, Dominique. Iniciação à prática sociológica. Petrópolis, RJ, Vozes, 1998.

MACHADO, Giancarlo Marques Carraro. Dilemas em torno da prática do street skate em São Paulo. Esporte e Sociedade, v. 19, pp. 1-24, 2012.

MAGNANI, José Guilherme Cantor. Circuito de jovens. In: MAGNANI, José Guilherme Cantor. Da periferia ao centro: trajetórias de pesquisa em antropologia urbana. São Paulo, Editora Terceiro nome, 2012.

MAYER, Adrian C. A importância dos quase grupos no estudo das sociedades complexas. In: FELDMAN-BIANCO, Bela (Org.). Antropologia das sociedades contemporâneas: métodos. São Paulo, Editora UNESP, 2010, pp. 139-171.

MOORE, Rob. Capital. In: Pierre Bourdieu: conceitos fundamentais. Petrópolis, RJ, Vozes, 2018.

NOVAES, Regina. Os jovens de hoje: contextos, diferenças e trajetórias. In: ALMEIDA, Maria Isabel Mendes de; EUGENIO, Fernanda (orgs.) Culturas jovens: novos mapas do afeto. Rio de Janeiro, Jorge Zahar Ed., 2006, pp. 105-120.

NUNES, João Arriscado. Erving Goffman, a análise de quadros e a sociologia da vida quotidiana. Revista Crítica de Ciências Sociais, 37, Coimbra, CES, pp. 33-49, 1993.

PAIS, JOSÉ Machado. A construção sociológica da juventude-alguns contributos. Análise social, v. 25, n. 105-106, pp. 139-165, 1990. 
PEREIRA, Alexandre Barbosa. As Imaginações da Cidade: práticas culturais juvenis e produção imagética. Revista Iluminuras, v. 18, pp. 11-37, 2017.

SIMMEL, Georg. Questões Fundamentais de Sociologia: indíviduo e sociedade. Rio de Janeiro, Zahar, 2006.

Conflito e estrutura de grupo. In: MORAES FILHO, Evaristo (Org.). Simmel: Sociologia. São Paulo, Ática, 1983, pp. 150-164.

. A Natureza Sociológica do conflito. In: MORAES FILHO, Evaristo (Org.). Simmel: Sociologia. São Paulo, Ática, 1983, pp. 122-134.

TELLES, Vera da Silva. A cidade nas fronteiras do legal e ilegal. Belo Horizonte, MG, Fino Traço, 2010.

WHYTE, William Foote. Sociedade de esquina. Rio de Janeiro, Jorge Zahar Editor, 2005.

Recebido em: 24/03/2018

Aprovado em: 04/07/2019

\section{Como citar este artigo:}

PEREIRA, Jesus Marmanillo. Streeteiros e a cidade: Sociabilidades, itinerários institucionalização do skate em Imperatriz-MA. Contemporânea - Revista de Sociologia da UFSCar, v. 9, n. 3, set.- dez. 2019, pp. 963-987. 